\title{
Jordanian Teachers' Awareness of Their Role in the Classroom
}

\author{
Mohammad Ahmed Al-Jabali \\ King Saud University, Saudi Arabia \\ Mohammed Mahmoud Obeidat \\ King Saud University, Saudi Arabia
}

\begin{abstract}
This study aimed at investigating the Jordanian teachers' awareness of their roles in the classroom. The independent variables investigated were gender, experience, and specialization, teaching load, and academic qualifications. A questionnaire was used to collect the data necessary to answer the study questions. Correlation coefficient, Five-way ANOVA, means, and standard deviations were used to analyze the data collected. The sample of the study consisted of Jordanian teachers working at Jordanian schools in rural areas in the North of Jordan. The findings of the study revealed that Jordanian teachers' awareness of role Applicability and Practice was "High". The "High" awareness of role was attributed to many different reasons.
\end{abstract}

Index Terms - language teacher, role, awareness, Jordanian, communicator

\section{INTRODUCTION}

Teaching is a hard job as it dictates various responsibilities and changes upon the teacher's character and behavior. Teaching was part, if not the whole part, of the messages of all Prophets and Messengers. Our Messenger, Mohammad (Peace be upon him), praised the job of the teacher by saying "Hadn't I been a messenger, I would have been a teacher." This means that the word "teacher" is not exclusive to schools and educated people and educators who are expected to practice this role.

Lanier (n.d.) viewed the process of teaching by saying: "Teaching is recognized as one of the most challenging and respected choices, absolutely vital to the social, cultural, and economic health of our nation." Shishavan (2010, p. 1) states that "Teachers in general and English Language teachers in particular play a fundamental role in their learners' learning and academic achievement". Choudhury $(2011$, p. 34) adds that "the teacher in the classroom is of paramount significance because it is central to the way in which the classroom environment evolves." Teachers have to adapt with all the teaching process inputs: students, curriculum, classroom environment, students' parents, the society, and the principals. They have to deal with each case separately. They have to adapt with all students' conditions and psychological problems. These requirements require the teacher to perform various roles during the day, or sometimes the lesson. Veira (2012, p. 1) asserts that "Teachers perform different roles when making decisions about the planning and teaching of lessons". The definition of the word "role" by Banten (1965) means what is expected from some kind of behavior.

The significance and rationale of this study stem from its comprehensiveness of roles gathered from the literature devoted to the teacher's role in the foreign language classroom as a first step, and from its attempt to find out the levels of teachers' awareness of both: Applicability of the roles on Jordanian teachers of language and level of Practice of these roles by them. It, moreover, hopes to let Jordanian teachers know the shift in language teacher's roles in accordance with Choudhury (2011, p. 34) words "Teachers must be clear about their role in the classroom so that there is no chasm between their perceptions of their role and what they actually practice in the classroom".

The study aimed to investigate the level of applicability of teacher's roles on the Jordanian teacher of language, and the level of Practice of these roles by the Jordanian English teacher of language, as well. Therefore, this study sought to answer the following questions: 1) what is the level of applicability of teacher's roles on Jordanian teachers of language? 2) Are there any significant differences of Applicability of teacher's roles on Jordanian teachers of language among respondents' responses due to teacher's gender, major, university degree, experience, or stage teaching load at $\alpha=0.05$ ? 3) What is the level of Practice of teacher's roles by Jordanian teachers of language? 4) Are there any significant differences in Practice of teacher's role by Jordanian teachers of language among respondents' responses due to teacher's gender, university degree, experience, major, or stage teaching load at $\alpha=0.05$ ? 5) Is there any significant congruence between Applicability and Practice of teacher's roles by Jordanian teachers of language?

\section{LITERATURE REVIEW}

Language teaching methods and approaches assigned different roles to the teacher that probably stemmed from their philosophies and conditions they were devised in. The Oral Approach and Situational Language Teaching viewed the 
teacher as a skillful conductor of an orchestra from learners (Byrne, 1976, p. 3), and a skillful manipulator to elicit correct sentences from learners, and to set the pace for learning. That is, classes were teacher-directed ones. The Audiolingual Method was a teacher-dominated one as the teacher models the target language, controls the direction and pace of learning and monitors and corrects the learners' performance (Richards \& Rodgers 2003, p. 62). The Total Physical Response viewed the teacher's role as a provider of opportunities for learning. It also suggests that the teacher should behave like a parent in correcting students' mistakes and giving feedback depending on the learner's age. Stevick (1980, p. 56) summarized the teacher's roles for The Silent Way as "to teach, to test, and to get out of the way".

The Suggestopedia assumed that the teacher's primary role is to create situations for good language learning (Richards \& Rodgers 2003, p. 104). The Whole Language Approach pointed out that the teacher's roles were a facilitator and an active participant in the learning community. Concerning The Multiple Intelligences Theory, Campbell (1997, p. 19) indicated that the teacher has to construct and develop the curriculum and be professional in as s/he has to improve her/himself as an educator.

Communicative Language Teaching Approach had assigned two main roles for the teacher. The first is a facilitator of the communication process, and the second is a participant within the learning-teaching group. However; these roles imply some secondary ones like: organizer of resource and as resource himself, guide within the class, researcher, learner, needs analyst, counselor, and group process manager (Breen \& Candlin, 1980, p. 99). The Natural Approach named three roles for the teacher. First, the teacher is a primary source of comprehensible input in the target language. Second, the teacher is a creator of an interesting and friendly atmosphere for learning. Third, the teacher is a selector of rich activities and content that suit students' needs and interests. In terms of The Cooperative Language Learning Approach, Johnson, Johnson, and Holubec (1994) described the teacher's role as a facilitator and has to create a highly structured and well-organized learning environment in the classroom like selecting the material and time.

As for Content-Based Instruction and Task-Based Instruction, somehow different roles had been identified for the language teacher. In Content-Based Instruction, the teacher must be knowledgeable in the subject matter and able to elicit knowledge from learners (Stryker \& Leaver 1993, p. 292). Moreover, the teacher should become student needs analyst, and create truly learner-centered classrooms (Brinton, Snow, and Wesche, 1989, p. 3). Task-Based Instruction assumed clear roles for the language teacher. These include: Selecting and sequencing of tasks, preparing learners for tasks, and consciousness-raising (Richards \& Rodgers 2003, p. 236).

Brown (2001) mentioned some roles for the interactive teacher. These roles are: controller, director, manager, facilitator, and resource. Harden and Crosby (2000) reviewed the literature relating to the roles of the teacher and summarized them in the following areas: information provider, role model, facilitator, assessor, planner, and resource developer.

Arafat (2005) investigated eight roles of the English Language teacher as perceived by university TEFL students of all levels. The findings showed that the perception for the roles "investigator" and participant was Very High; and it was High for all other roles investigated namely: "resource", "prompter", "organizer", "tutor", "assessor", and "controller" respectively. However, the findings also revealed no significant differences for the gender variable. Jin (2008) described the role language teacher in accordance with communicative language teaching as a facilitator, guide, advice giver when necessary, participant, activator, and communicator.

Huijie (2012) attributed the change and shift in the language teacher's roles from those of a ruler and dominant to those of an advisor and a facilitator to the theory of constructivism when the teaching pattern changed from teachercentered to learner-centered. Huijie revealed that a language teacher should be a manager and organizer of the language teaching class, a designer of the teaching process, a source of the teaching material, an investigator and a counselor of students' learning and a promoter of deepening and confirming the accepted knowledge.

Keblowska (2002) revealed that teachers suggested thirteen roles for the teacher; three of these roles were teacher's role behavior (organizer, instructor, \& controller); five were task-related roles (facilitator, counselor, participant, expert/resource, \& evaluator); three were interpersonal roles (creator of conditions conducive to learning, friend, and socializing agent; two were called special roles (motivator, \& learner). Teachers' responses showed that the most important roles were: instructor, motivator, counselor and socializing agent respectively. However, the most common roles: instructor, expert/source, evaluator, \& organizer respectively. The observations revealed that the roles that were always present were: organizer, evaluator, instructor, \& controller while the roles which were rarely present were: motivator, friend, participant, \& learner.

Simon (2002) and Yuveinco and Huang (2005) investigated the English Language roles in distance learning and elearning respectively. Simon's study revealed that the English Language teacher practices five roles through distance learning namely: technologist, process facilitator, content expert, instructions' designer, and manager. Yuveinco and Huang's revealed that the English Language teacher practices four roles through e-learning namely: facilitator of learning, advice-giver, educational and technological supporter and provider.

This review reflects the importance of the role of language teacher that was considered an important component of all methods and approaches proposed for teaching a foreign or second language. Richards and Rodgers (2003), in their discussion of the teaching methods and approaches, talk about the language teacher's roles. Willis (1990, p. 131) views the language teacher's role as one of creating an environment in which learners can operate effectively and the helping learners manage their own learning. Mohan (2012, p. 35) describes metaphorically the teacher's role during the three 
stages of the lesson (presentation, practice, and production) as the role of information and environment architects. Richards and Rodgers (2003, p. 29) state that: "The role of the teacher will ultimately reflect both the objectives of the method and the learning theory on which the method is predicated, since the success of a method may depend on the degree to which the teacher can provide the content or create the conditions for successful language learning." This implies that various roles are expected from the teacher to fulfill. Some of these roles are seen and expected through the mentioned statement "provide the content" while other roles are not seen at the moment and they are embedded in the phrase "create the conditions for successful language learning". This latter phrase implies the various developments in the teaching-learning process, and the development of societies.

Littlewood (1981) and Harmer (2001) look at the language teacher's role in the classroom as a facilitator from two somehow different angles. Littlewood (p. 92) broadens this role and entails some sub-roles with it. These sub-roles are: overseer of students' learning, classroom manager, consultant or advisor of students and sometimes co-communicator. However, Harmer looks the "facilitator" in a much broader form than Littlewood does as all teacher's roles are meant to facilitate the progress of the learner in some way or another. He adds that the teacher has the roles of controller, organizer, assessor, participant, resource, tutor, and observer.

To sum up, there are still some roles, for the language teacher, which have not been investigated yet. Furthermore, there are some variables which might be affecting the language teacher's roles that have not been investigated right now. This study will hopefully reveal the impact of other variables affecting the teacher's role so as to introduce some contribution to the field or give insights for new ideas to other researchers.

\section{Methodology}

\section{A. Sample, Data Collection Tools and Analysis}

A Four-Likert questionnaire consisting of two halves containing 31 teacher roles (Appendix A), one for role Applicability and the other for role Practice, was used to collect the necessary data from the volunteer respondents. The correction scale had three levels for mean scores: 1 to 1.99 was considered "Low"; 2 to 2.99 was considered "Moderate"; and 3 to 4 was considered "High". Most of these roles have been taken from the literature on the language teacher's roles. The researchers dropped the role of "facilitator" as they believe that this role is so comprehensive and entails a lot of other roles in accordance with Harmer (2001) and Littlewood (1981). Concerning the domains of the questionnaire, the researchers adopted Keblowska's (2002). Regarding the insertion of the additional roles not mentioned in Keblowska (2002) into the four domains, the researchers resorted to experts in the field of language teaching and their own experience. The questionnaire also included the independent variables of the study. The sample consisted of 245 teachers of Arabic and English Languages. All participants are Jordanians, teach in rural schools that lave a few facilities, have their full load of teaching, and work in schools not far away from their living areas. The distribution of the sample according to the study variables is presented in Table 1.

TABLE 1

DISTRIBUTION OF SAMPLE ACCORDING TO STUDY VARIABLES

\begin{tabular}{llll}
\hline $\begin{array}{l}\text { Independent } \\
\text { Variables }\end{array}$ & Levels & Frequency & Percent \\
\hline Major & Arabic & 106 & 43.3 \\
& English & 139 & 56.7 \\
\hline Experience & 1 to 5 & 57 & 23.3 \\
& 6 to 10 & 87 & 35.5 \\
& 11 to 15 & 39 & 15.9 \\
& 16 and above & 62 & 25.3 \\
\hline Gender & Male & 147 & 60.0 \\
& Female & 98 & 40.0 \\
\hline Load & 1 to 6 & 63 & 25.7 \\
& 7 to 10 & 112 & 45.7 \\
& Secondary & 70 & 28.6 \\
\hline Academic & Bachelor & 179 & 73.1 \\
Qualification & High Diploma & 32 & 13.1 \\
& Master and above & 34 & 13.9 \\
\hline Total & & $\mathbf{2 4 5}$ & $\mathbf{1 0 0 . 0}$ \\
\hline
\end{tabular}

\section{B. Study Tools' Validity and Reliability}

To investigate the construct validity of the role Applicability part on Jordanian teachers of language and its Practice by them, Pearson Correlation formula between the items and the tool as a whole unit with all its domains was calculated on a pilot sample consisting of 30 teachers from outside the sample of the study. The correlation coefficient for Applicability ranged between 0.45-0.68 at the domain level and it was between 0.38-0.63 at the whole tool level. This means that correlation coefficient was high at both levels: the domains, and whole scale. The results are presented in Appendix D. 
However, the correlation coefficient for Practice ranged between 0.42-0.72 at the domain level and it was between 0.26-0.63 at the whole tool level. This means that correlation coefficient was high at both levels: the domains, and whole scale. The results are presented in Appendix E.

To investigate the internal validity, Pearson Correlation formula between the domains and the tool from one hand and between the domains from another hand was calculated. The correlation between the domains and the tool ranged between 0.84-0.93 and between 0.61-0.77 between the domains. This indicates that correlation coefficient was very high at both levels: the domains, and whole scale.

In answering the questions of the study, various statistical devices were used. Means and standard deviations were used to answer the first and third questions. Means and standard deviations followed with Five-Way ANOVA (without interaction for both tools) and Multi Five-Way ANOVA (without interaction for study domains), according to study variables, were used to answer the second and fourth questions. Pearson's Correlation Coefficient between the study tools and their domains were used to answer the fifth question.

\section{Reliability of Study Tool}

The reliability of internal congruence for the study tool and its domains was counted using Cronbach Alpha Formula on the piloting sample and Stability Index was counted after 21 days of the first application using Cronbach's Alpha Formula. The results are presented in Table 2.

TABLE 2

VALUES OF INTERNAL CONGRUENCE AND STABILITY INDEX

\begin{tabular}{llll}
\hline $\begin{array}{l}\text { Level of Applicability on Language } \\
\text { Teacher and its Domains }\end{array}$ & $\begin{array}{l}\text { Cronbach's } \\
\text { Alpha }\end{array}$ & $\begin{array}{l}\text { Stability } \\
\text { Index }\end{array}$ & $\begin{array}{l}\text { N of } \\
\text { Items }\end{array}$ \\
\hline Task-Related Roles & 0.75 & $\mathbf{0 . 8 5}$ & 10 \\
Interpersonal Roles & 0.76 & $\mathbf{0 . 8 9}$ & 7 \\
Role Behavior & 0.70 & $\mathbf{0 . 8 8}$ & 9 \\
Special Roles & 0.73 & $\mathbf{0 . 9 2}$ & 5 \\
\hline Over Whole & $\mathbf{0 . 9 0}$ & $\mathbf{0 . 8 6}$ & $\mathbf{3 1}$ \\
\hline
\end{tabular}

\section{Findings OF THE STUDY}

To answer the first question: "What is the level of Applicability of teacher's roles on Jordanian teachers of language?", mean scores and standard deviations for the level of Applicability of teacher's roles on Jordanian teachers of language were calculated (as a whole with domains) taking into consideration a descending order of the domains according to their mean scores. The results are presented in Table 3.

TABLE 3

MEAN SCORES AND STANDARD DEVIATIONS FOR THE LEVEL OF APPLICABILITY OF TEACHER'S ROLES ON JORDANIAN TEACHERS OF LANGUAGE

\begin{tabular}{lllll}
\hline Rank & $\begin{array}{l}\text { Domain } \\
\text { ID }\end{array}$ & $\begin{array}{l}\text { Level of Applicability } \\
\text { on Language Teacher }\end{array}$ & Mean & $\begin{array}{l}\text { Std. } \\
\text { Dev. }\end{array}$ \\
\hline 1 & 4 & Special Roles & 3.356 & 0.44 \\
2 & 1 & Task-Related Roles & 3.283 & 0.41 \\
3 & 2 & Interpersonal Roles & 3.228 & 0.42 \\
4 & 3 & Role Behavior & 3.195 & 0.42 \\
\hline Over Whole & & $\mathbf{3 . 2 5 7}$ & $\mathbf{0 . 3 8}$ \\
\hline
\end{tabular}

Table 3 shows that the level of Applicability of teacher's roles on Jordanian teachers of language is High (3.257). The Special Roles domain came first; the Task-Related Roles domain came second; the Interpersonal Roles came third, and the Role Behavior came last in forth position.

To answer the second question: “Are there any significant differences of Applicability of teacher's roles on Jordanian teachers of language among respondents' responses due to teacher's gender, major, university degree, experience, or stage teaching load at $\alpha=0.05$ ?", mean scores and standard deviations for the level of Applicability of teacher's roles on Jordanian teachers of language were calculated (as a whole) according to the variables of the study. The results are presented in Table 4. 
TABLE 4

MEAN SCORES AND STANDARD DEVIATIONS OF APPLICABILITY OF TEACHER'S ROLES ON JORDANIAN TEACHERS OF LANGUAGE ACCORDING TO STUDY VARIABLES

\begin{tabular}{llll}
\hline $\begin{array}{l}\text { Independent } \\
\text { Variables }\end{array}$ & Levels & Mean & $\begin{array}{l}\text { Std. } \\
\text { Dev. }\end{array}$ \\
\hline Major & Arabic & 3.322 & 0.36 \\
& English & 3.207 & 0.38 \\
\hline Experience & 1 to 5 & 3.233 & 0.35 \\
& 6 to 10 & 3.248 & 0.40 \\
& 11 to 15 & 3.235 & 0.32 \\
& 16 and above & 3.305 & 0.41 \\
\hline Gender & Male & 3.273 & 0.38 \\
& Female & 3.232 & 0.36 \\
\hline Load & 1 to 6 & 3.308 & 0.38 \\
& 7 to 10 & 3.232 & 0.38 \\
& Secondary & 3.251 & 0.36 \\
\hline Academic & Bachelor & 3.238 & 0.38 \\
Qualification & High Diploma & 3.267 & 0.35 \\
& Master and above & 3.346 & 0.39 \\
\hline
\end{tabular}

Table 4 shows that there were observed differences between the mean scores and standard deviations for the level of Applicability of teacher's roles on Jordanian teachers of language resulting from difference of levels of the study variables. To investigate the significance of these observed differences, Five-Way ANOVA (without interaction) was carried out for the level of Applicability of teacher's roles on Jordanian teachers of language according to the variables of the study. The results are presented in Table 5.

TABLE 5

RESULTS OF FIVE-WAY ANOVA (WITHOUT INTERACTION) FOR THE LEVEL OF APPLICABILITY OF TEACHER'S ROLES ON JORDANIAN TEACHERS OF LANGUAGE ACCORDING TO THE VARIABLES OF THE STUDY

\begin{tabular}{llllll}
\hline Source & Sum of Squares & df & Mean Square & F & Sig. \\
\hline Major & 0.763 & 1 & 0.763 & $\mathbf{5 . 5 0 1}$ & 0.020 \\
Experience & 0.216 & 3 & 0.072 & 0.519 & 0.669 \\
Gender & 0.073 & 1 & 0.073 & 0.529 & 0.468 \\
Load & 0.425 & 2 & 0.213 & 1.533 & 0.218 \\
Qualification & 0.325 & 2 & 0.163 & 1.173 & 0.311 \\
Error & 32.59 & 235 & 0.139 & & \\
Total & 34.323 & 244 & & & \\
\hline
\end{tabular}

Table 5 shows that there is a significant difference at $\alpha=0.05$ between the two mean scores of the level of Applicability of teacher's roles on Jordanian teachers of language ascribed for "major" variable for the teachers of Arabic Language when compared with the teachers of English Language. However, the other variables of the study (teacher's gender, university degree, experience, and stage teaching load) did not show any significant difference.

To answer the third question: "What is the level of Practice of teacher's roles by Jordanian teachers of language?", mean scores and standard deviations for the level of Practice of teacher's roles on Jordanian teachers of language were calculated (as a whole with domains) taking into consideration a descending order of the domains according to their mean scores. The results are presented in Table 6.

TABLE 6

MEAN SCORES AND STANDARD DEVIATIONS FOR THE LEVEL OF PRACTICE OF TEACHER's ROLES By JORDANIAN TEACHERS OF LANGUAGE

\begin{tabular}{lllll}
\hline Rank & $\begin{array}{l}\text { Domain } \\
\text { ID }\end{array}$ & $\begin{array}{l}\text { Level of Practice by } \\
\text { Language Teacher }\end{array}$ & Mean & $\begin{array}{l}\text { Std. } \\
\text { Dev. }\end{array}$ \\
\hline 1 & 4 & Special Roles & 3.298 & 0.46 \\
2 & 1 & Task-Related Roles & 3.273 & 0.40 \\
3 & 2 & Interpersonal Roles & 3.198 & 0.44 \\
4 & 3 & Role Behavior & 3.173 & 0.39 \\
\hline Over Whole & & $\mathbf{3 . 2 3 1}$ & $\mathbf{0 . 3 7}$ \\
\hline
\end{tabular}

Table 6 shows that the level of Practice of teacher's roles by Jordanian teachers of language is High (3.231). The Special Roles domain came first; the Task-Related Roles domain came second; the Interpersonal Roles came third, and the Role Behavior came last in forth position.

To answer the fourth question: “Are there any significant differences of Practice of teacher's roles by Jordanian teachers of language among the respondents' responses due to teacher's gender, major, university degree, experience, or stage teaching load at $\alpha=0.05$ ?", mean scores and standard deviations for the level of Applicability of teacher's roles on Jordanian teachers of language were calculated (as a whole) according to the variables of the study. The results are presented in Table 7. 
TABLE 7

MEAN SCORES AND STANDARD DEVIATIONS OF PRACTICE OF TEACHER's ROLES By JORDANIAN TEACHERS OF LANGUAGE ACCORDING TO STUDY VARIABLES

\begin{tabular}{llll}
\hline Independent Variables & Levels & Mean & Std. Dev. \\
\hline Major & Arabic & 3.267 & 0.34 \\
& English & 3.204 & 0.38 \\
\hline Experience & 1 to 5 & 3.257 & 0.34 \\
& 6 to 10 & 3.205 & 0.33 \\
& 11 to 15 & 3.242 & 0.28 \\
& 16 and above & 3.237 & 0.48 \\
\hline Gender & Male & 3.229 & 0.38 \\
& Female & 3.234 & 0.34 \\
\hline Load & 1 to 6 & 3.226 & 0.36 \\
& 7 to 10 & 3.209 & 0.37 \\
& Secondary & 3.270 & 0.37 \\
\hline Academic & Bachelor & 3.227 & 0.34 \\
Qualification & High Diploma & 3.164 & 0.46 \\
& Master and above & 3.315 & 0.39 \\
\hline
\end{tabular}

Table 7 shows that there were observed differences between the mean scores and standard deviations for the level of Practice of teacher's roles by Jordanian teachers of language resulting from the various levels of the study variables. To investigate the significance of these observed differences, Five-way ANOVA (without interaction) was carried out for the level of Practice of teacher's roles on Jordanian teachers of language according to the variables of the study. The results are presented in Table 8.

TABLE 8

RESULTS OF FIVE-WAY ANOVA (WITHOUT INTERACTION) FOR THE LEVEL OF PRACTICE OF TEACHER'S ROLES ON JORDANIAN TEACHERS OF LANGUAGE ACCORDING TO THE VARIABLES OF THE STUDY

\begin{tabular}{llllll}
\hline Source & Sum of Squares & df & Mean Square & F & Sig. \\
\hline Major & 0.217 & 1 & 0.217 & 1.607 & 0.206 \\
Experience & 0.104 & 3 & 0.035 & 0.256 & 0.857 \\
Gender & 0.000 & 1 & 0.000 & 0.001 & 0.974 \\
Load & 0.200 & 2 & 0.100 & 0.740 & 0.478 \\
Qualification & 0.377 & 2 & 0.188 & 1.394 & 0.250 \\
Error & 31.762 & 235 & 0.135 & & \\
Total & 32.659 & 244 & & & \\
\hline
\end{tabular}

Table 8 shows that there were no significant differences at $\alpha=0.05$ between the two mean scores of the level of Practice of teacher's roles by Jordanian teachers of language ascribed for any of the variables of the study.

To answer fifth question "Is there any significant congruence between Applicability and Practice of teacher's roles by Jordanian teachers of language?", correlation coefficient between the level of Applicability of teacher's roles with its domains from one hand and the level of Practice of teacher's roles with its domains from another hand. The results are presented in Table 9.

TABLE 9

VALUES OF CORRELATION BETWEEN APPLICABILITY AND PRACTICE OF TEACHER'S ROLES By JORDANIAN TEACHERS OF LANGUAGE

\begin{tabular}{lcc}
\hline $\begin{array}{l}\text { Correlation between } \\
\text { Level of Applicability on Language Teacher }\end{array}$ & Sig. \\
With Level of Practice by Language Teacher & \\
\hline Task-Related Roles & $\mathbf{0 . 5 9}$ & 0.000 \\
Interpersonal Roles & $\mathbf{0 . 5 5}$ & 0.000 \\
Role Behavior & $\mathbf{0 . 5 3}$ & 0.000 \\
Special Roles & $\mathbf{0 . 5 0}$ & 0.000 \\
\hline Over Whole & $\mathbf{0 . 6 0}$ & 0.000 \\
\hline
\end{tabular}

Table 9 shows that the values of correlation between the level of Applicability and its domains on Jordanian teachers of language from one hand and the level of Practice and its domains by Jordanian teachers of language from another hand was statistically significant at $\alpha=0.05$ between. It was positive and could be classified as "moderate correlation" according to the criterion of Hinkle (Weirsma \& Jurs, 1988).

\section{DisCuSSION OF THE FINDINGS}

The discussion of the findings will be divided into two parts. The first part will be devoted for the first, third and fifth questions as the first and third are both descriptive ones and the fifth question links between them. The second part of the discussion will be devoted to the second and fourth questions as these questions are analytical.

The findings to the first and third questions in Appendix E and Table 4 revealed that the levels of teacher's role Applicability and Practice were High. This finding agrees with Arafat (2005). The findings also match with some of the studies in the review of literature only in some of the roles investigated. They match with Harden \& Crosby (2000), 
Keblowska (2002), and Arafat (2005) in the role of "assessor" that meets the role of "evaluator of pupils' learning" in the current study. They match with Jin (2008) in the roles of "guide" and "communicator"; and with Arafat (20050, and Huijie (2012) in 'organizer", "promoter", and "counselor"; and with Yuveinco \& Huang (20050 and Arafat (2005) in the role of "supporter".

However, the mean score for role Applicability (3.257) was higher than that for role Practice (3.231). This difference in mean scores did not reveal any significant difference for question five between role Applicability and role Practice. This High level of Applicability of the role on Jordanian teachers of language might be the fruit of the in-service training programs which teachers of language attend now and then, or reflection of teachers' satisfaction of the recent increase in their salaries and the rights obtained such as obtaining scholarships for their sons and forming the Teachers' Association.

However, this difference between Applicability and Practice strengthens the gap between theory and practice as role Applicability, here, represents theory. This could, also, mean that Jordanian teachers of language do not practice what they think applies on them as the fruit of the in-service-training programs has not ripened yet.

Concerning the analytical questions, the variable of "major" in question 2 for role Applicability revealed a significant difference on behalf of Arabic Language teachers whereas question 4 for role Practice did not reveal any significant differences for any of the study variables. In terms of the significant difference on behalf of Arabic teachers, it could be attributed to many reasons. The first reason can be the large number of weekly hours- 6 hours on average for all stagesfor teaching Arabic when compared with the number of hours devoted to English classes- 4 hours on average for all stages. This large number of classes might give the teachers of Arabic a greater chance to think that these roles really apply on them while Jordanian English Language teachers might not have this chance. The second reason could be the Arabic teachers' deeper understanding of the explicit or implicit meaning of each of the roles included in the questionnaire. The third reason could be the type of learning material included in the Arabic curricula includes lots of religious texts that regulate life. The fourth reason might be ascribed for the Arabic teachers' background affected by the literature courses they studied at university. The fifth reason could result from the easiness of communication between the Arabic teachers and their students as they both use the native language when compared with the teachers of English where lots of students might not understand everything explained in the classroom. This could affect the teacher's role by creating a feeling of frustration and nervosity that leads to a change in teacher's roles.

Although the findings to question 4 did not reveal any significant differences for any of the study variables, there are certain points that should be raised with reference to Appendixes B and C. First, all items in the domains of "Interpersonal Roles" and "Special Roles" obtained the same order in both cases of role "Applicability" and "Practice". This could be ascribed to the smaller number of items in each of these two domains when compared with the other two domains. Second, three items of each of the domains of "Task-Related Roles" and "Role Behavior" obtained the same ranks in both cases of role "Applicability" and "Practice"; items "1, 4, and 2" of "Task-Related Roles" domain and items "23, 7, and 10" of the "Role Behavior" domain. Third, the mean scores for 19 items retreated in Practice while 11 items increased and only 1 (Instructor) obtained the same mean score in both cases "Applicability" and "Practice".

\section{CONCLUSION AND RECOMMENDATIONS}

This study has set out to examine the Jordanian English and Arabic Languages' teachers' awareness of their roles in the classroom. It has shown that teachers exhibited a High level of awareness with regard to role Applicability and Practice. The results also revealed a significant difference for the Specialization variable. It can be concluded that Jordanian teachers of language still have much impact of schooldays that in-service training programs have not yet overcome regardless their experience, academic qualification, or gender. This is represented by the high mean scores of roles indicating teacher-centered classes such as: taskmaster, disciplinarian, instructor, and manager. Jordanian teachers of language still apply the traditional role of the teacher despite the modern curriculum adopting the latest methods of teaching than contain activities which minimize the teacher-centered classroom and optimize the learner-centered classroom.

It is recommended that teachers should be subjected to more specialized pre-service and in-service training programs and workshops that concentrate on modern teachers' roles in the classroom; and the supervisors should follow-up the activation of these programs. More studies should be carried out to investigate the effect of other variables on language teachers' roles.

\section{ACKNOWLEDGEMENT}

The researchers would like to thank the Research Center of the College of Languages and Translation - Deanship of Scientific Research - King Saud University for the support offered to this research. 
ApPendix A Data Collection Questionnaire

\begin{tabular}{|c|c|c|c|c|c|c|c|c|c|}
\hline \multirow[t]{2}{*}{ No } & \multirow[t]{2}{*}{ Role } & \multicolumn{4}{|c|}{$\begin{array}{l}\text { Level of Applicability on Language } \\
\text { Teacher }\end{array}$} & \multicolumn{4}{|c|}{ Level of Practice by Language Teacher } \\
\hline & & $\begin{array}{l}\text { To a } \\
\text { large } \\
\text { extent }\end{array}$ & $\begin{array}{l}\text { To } \\
\text { some } \\
\text { extent }\end{array}$ & $\begin{array}{l}\text { To a } \\
\text { little } \\
\text { extent }\end{array}$ & $\begin{array}{l}\text { Does } \\
\text { not } \\
\text { apply }\end{array}$ & $\begin{array}{l}\text { To a } \\
\text { large } \\
\text { extent }\end{array}$ & $\begin{array}{l}\text { To } \\
\text { some } \\
\text { extent }\end{array}$ & $\begin{array}{l}\text { To a } \\
\text { little } \\
\text { extent }\end{array}$ & $\begin{array}{l}\text { Not } \\
\text { practiced }\end{array}$ \\
\hline 1 & $\begin{array}{l}\text { Communicator: He transmits information, } \\
\text { content, thoughts to the pupils. }\end{array}$ & & & & & & & & \\
\hline 2 & $\begin{array}{l}\text { Counselor: He understands his pupils' } \\
\text { personal and academic problems and } \\
\text { acquaints them with post-educational choices. }\end{array}$ & & & & & & & & \\
\hline 3 & $\begin{array}{l}\text { Collaborator: He joins hands in performing } \\
\text { his task with his colleagues. }\end{array}$ & & & & & & & & \\
\hline 4 & $\begin{array}{l}\text { Consultant: He enjoys the confidence of } \\
\text { pupils and advises them. }\end{array}$ & & & & & & & & \\
\hline 5 & $\begin{array}{l}\text { Cultural Agent: He seeks to preserve and } \\
\text { transmit the cultural heritage to posterity. }\end{array}$ & & & & & & & & \\
\hline 6 & $\begin{array}{l}\text { Evaluator of pupils' learning in terms of } \\
\text { their achievements, abilities and lapses. }\end{array}$ & & & & & & & & \\
\hline 7 & $\begin{array}{l}\text { Innovator: He innovates, performs, and } \\
\text { improves the techniques, content, } \\
\text { activities....etc. }\end{array}$ & & & & & & & & \\
\hline 8 & $\begin{array}{l}\text { Instructor: He imparts instructions by way of } \\
\text { direction and order. }\end{array}$ & & & & & & & & \\
\hline 9 & $\begin{array}{l}\text { Leader: He acts as a leader in the matter of } \\
\text { educational reconstruction. }\end{array}$ & & & & & & & & \\
\hline 10 & $\begin{array}{l}\text { Manager: He organizes, supervises, and } \\
\text { manages institutional affairs and problems. }\end{array}$ & & & & & & & & \\
\hline 11 & $\begin{array}{l}\text { Model: He commands perfection as a teacher } \\
\text { and serves as a source of inspiration. }\end{array}$ & & & & & & & & \\
\hline 12 & $\begin{array}{l}\text { Monitor: He monitors the course of true } \\
\text { education in every aspect. }\end{array}$ & & & & & & & & \\
\hline 13 & $\begin{array}{l}\text { Motivator: He stimulates and sustains active } \\
\text { interest through various techniques. }\end{array}$ & & & & & & & & \\
\hline 14 & $\begin{array}{l}\text { Organizer of pupils' activities and supervises } \\
\text { approved program of activities in and outside } \\
\text { the school. }\end{array}$ & & & & & & & & \\
\hline 15 & $\begin{array}{l}\text { Pupil guide: He directs pupils in the conduct } \\
\text { and way of life. }\end{array}$ & & & & & & & & \\
\hline 16 & $\begin{array}{l}\text { Professionalist: He keeps himself awake for } \\
\text { his professional growth. }\end{array}$ & & & & & & & & \\
\hline 17 & $\begin{array}{l}\text { Promoter: He contributes to the growth and } \\
\text { welfare of his students. }\end{array}$ & & & & & & & & \\
\hline 18 & $\begin{array}{l}\text { Agent of social change: He changes in social } \\
\text { environment and perspective to realize the } \\
\text { objectives of a progressive society. }\end{array}$ & & & & & & & & \\
\hline 19 & $\begin{array}{l}\text { Supporter: He supports students by providing } \\
\text { material and physical facilities to help. }\end{array}$ & & & & & & & & \\
\hline 20 & $\begin{array}{l}\text { Moral Booster: He not only believes } \\
\text { righteously but also encourages uprightness } \\
\text { among his pupils. }\end{array}$ & & & & & & & & \\
\hline 21 & $\begin{array}{l}\text { Demonstrator: He shows and explains to his } \\
\text { students what he is doing. }\end{array}$ & & & & & & & & \\
\hline 22 & $\begin{array}{l}\text { Taskmaster: He assigns tasks, listens to } \\
\text { recitations, asks questions, corrects answers } \\
\text { and assigns marks. }\end{array}$ & & & & & & & & \\
\hline 23 & $\begin{array}{l}\text { Disciplinarian: He maintains order in the } \\
\text { classroom so as to control it. }\end{array}$ & & & & & & & & \\
\hline 24 & $\begin{array}{l}\text { Surrogate parent: He feels responsible for } \\
\text { the learner as a whole: his health, social } \\
\text { adjustment, recreation, emotional health, } \\
\text { character development, intellectual } \\
\text { development....and so on. }\end{array}$ & & & & & & & & \\
\hline 25 & $\begin{array}{l}\text { Therapist: He takes responsibility for the } \\
\text { psychological problems and mental health of } \\
\text { his pupils. }\end{array}$ & & & & & & & & \\
\hline 26 & $\begin{array}{l}\text { Midwife: He guides the pupil's thought } \\
\text { processes by asking him the questions that } \\
\text { will lead him eventually to come to wise } \\
\text { conclusions. }\end{array}$ & & & & & & & & \\
\hline
\end{tabular}




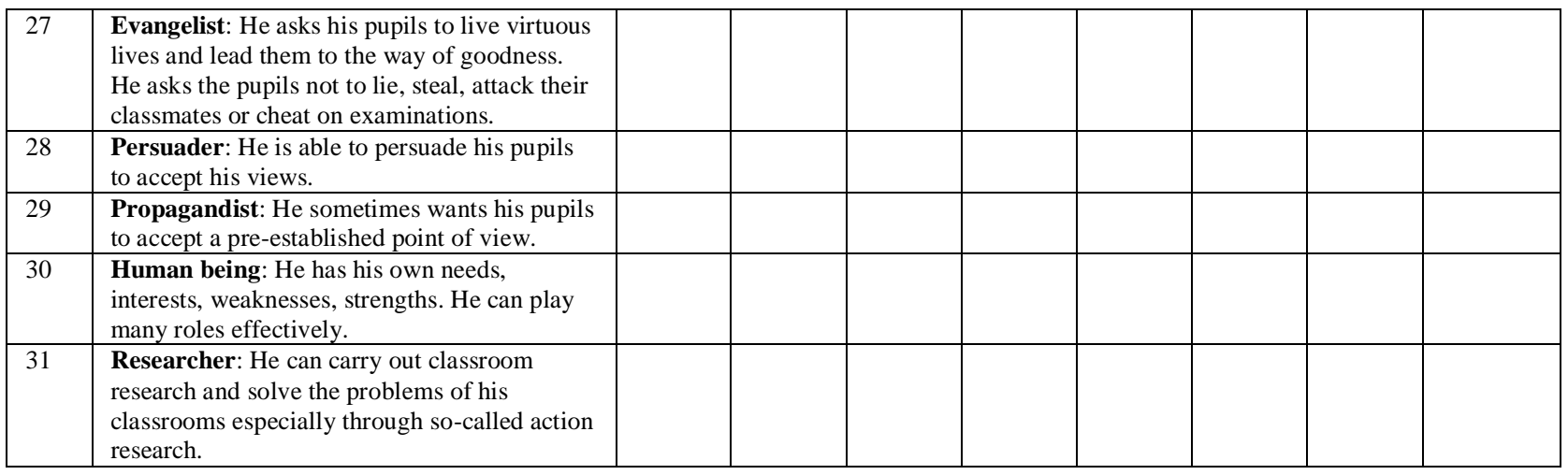

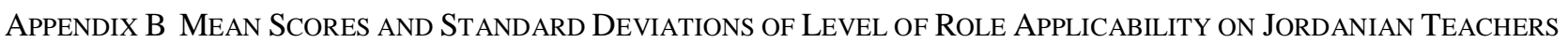

\begin{tabular}{|c|c|c|c|c|c|}
\hline Domain & Rank & $\begin{array}{l}\text { Item } \\
\text { ID }\end{array}$ & $\begin{array}{l}\text { Level of Applicability } \\
\text { on Language Teacher }\end{array}$ & Mean & $\begin{array}{l}\text { Std. } \\
\text { Dev. }\end{array}$ \\
\hline \multirow{10}{*}{$\begin{array}{l}\text { Task-Related } \\
\text { Roles }\end{array}$} & 1 & 1 & Communicator: He transmits information, content, thoughts to the pupils & 3.571 & 0.55 \\
\hline & 2 & 21 & Demonstrator: He shows and explains to his students what he is doing & 3.355 & 0.68 \\
\hline & 3 & 26 & $\begin{array}{l}\text { Midwife: He guides the pupil's thought processes by asking him the questions that will } \\
\text { lead him eventually to come to wise conclusions }\end{array}$ & 3.347 & 0.75 \\
\hline & 4 & 4 & Consultant: He enjoys the confidence of pupils and advises them & 3.335 & 0.77 \\
\hline & 5 & 22 & $\begin{array}{l}\text { Taskmaster: He assigns tasks, listens to recitations, asks questions, corrects answers and } \\
\text { assigns marks }\end{array}$ & 3.298 & 0.75 \\
\hline & 6 & 12 & Monitor: He monitors the course of true education in every aspect & 3.249 & 0.76 \\
\hline & 7 & 19 & Supporter: He supports students by providing material and physical facilities to help & 3.216 & 0.80 \\
\hline & 8 & 15 & Pupil guide: He directs pupils in the conduct and way of life & 3.196 & 0.76 \\
\hline & 9 & 16 & Professionalist: He keeps himself awake for his professional growth & 3.180 & 0.75 \\
\hline & 10 & 2 & $\begin{array}{l}\text { Counselor: He understands his pupils' personal and academic problems and acquaints } \\
\text { them with post-educational choices }\end{array}$ & 3.086 & 0.77 \\
\hline \multirow{7}{*}{$\begin{array}{l}\text { Interpersonal } \\
\text { Roles }\end{array}$} & 1 & 3 & Collaborator: He joins hands in performing his task with his colleagues & 3.490 & 0.66 \\
\hline & 2 & 28 & Persuader: He is able to persuade his pupils to accept his views & 3.392 & 0.67 \\
\hline & 3 & 6 & Evaluator of pupils' learning in terms of their achievements, abilities and lapses & 3.380 & 0.72 \\
\hline & 4 & 24 & $\begin{array}{l}\text { Surrogate parent: He feels responsible for the learner as a whole: his health, social } \\
\text { adjustment, recreation, emotional health, character development, intellectual } \\
\text { development... and so on }\end{array}$ & 3.224 & 0.76 \\
\hline & 5 & 29 & Propagandist: He sometimes wants his pupils to accept a pre-established point of view & 3.069 & 0.75 \\
\hline & 6 & 18 & $\begin{array}{l}\text { Agent of social change: He changes in social environment and perspective to realize the } \\
\text { objectives of a progressive society }\end{array}$ & 3.045 & 0.77 \\
\hline & 7 & 5 & Cultural Agent: He seeks to preserve and transmit the cultural heritage to posterity & 2.996 & 0.81 \\
\hline \multirow{9}{*}{$\begin{array}{l}\text { Role } \\
\text { Behavior }\end{array}$} & 1 & 23 & Disciplinarian: He maintains order in the classroom so as to control it & 3.473 & 0.69 \\
\hline & 2 & 11 & Model: He commands perfection as a teacher and serves as a source of inspiration & 3.327 & 0.74 \\
\hline & 3 & 27 & $\begin{array}{l}\text { Evangelist: He asks his pupils to live virtuous lives and lead them to the way of goodness } \\
\text { He asks the pupils not to lie, steal, attack their classmates or cheat on examinations }\end{array}$ & 3.302 & 0.78 \\
\hline & 4 & 9 & Leader: He acts as a leader in the matter of educational reconstruction & 3.273 & 0.72 \\
\hline & 5 & 8 & Instructor: He imparts instructions by way of direction and order & 3.196 & 0.78 \\
\hline & 6 & 7 & Innovator: He innovates, performs, and improves the techniques, content, activities... etc. & 3.159 & 0.73 \\
\hline & 7 & 14 & $\begin{array}{l}\text { Organizer of pupils' activities and supervises approved program of activities in and } \\
\text { outside the school }\end{array}$ & 3.020 & 0.78 \\
\hline & 8 & 25 & $\begin{array}{l}\text { Therapist: He takes responsibility for the psychological problems and mental health of his } \\
\text { pupils }\end{array}$ & 3.004 & 0.85 \\
\hline & 9 & 10 & Manager: He organizes, supervises, and manages institutional affairs and problems & 3.000 & 0.84 \\
\hline \multirow{5}{*}{$\begin{array}{l}\text { Special } \\
\text { Roles }\end{array}$} & 1 & 13 & Motivator: He stimulates and sustains active interest through various techniques & 3.616 & 0.51 \\
\hline & 2 & 20 & $\begin{array}{l}\text { Moral Booster: He not only believes righteously but also encourages uprightness among } \\
\text { his pupils }\end{array}$ & 3.490 & 0.66 \\
\hline & 3 & 17 & Promoter: He contributes to the growth and welfare of his students & 3.306 & 0.76 \\
\hline & 4 & 30 & $\begin{array}{l}\text { Human being: He has his own needs, interests, weaknesses, strengths } \mathrm{He} \text { can play many } \\
\text { roles effectively }\end{array}$ & 3.294 & 0.67 \\
\hline & 5 & 31 & $\begin{array}{l}\text { Researcher: He can carry out classroom research and solve the problems of his } \\
\text { classrooms especially through so-called action research }\end{array}$ & 3.073 & 0.83 \\
\hline
\end{tabular}


ApPendix C Mean Scores and Standard DeViations of LeVel of Role Practice by Jordanian Teachers

\begin{tabular}{|c|c|c|c|c|c|}
\hline Domain & Rank & $\begin{array}{l}\text { Item } \\
\text { ID }\end{array}$ & $\begin{array}{l}\text { Level of Practice by } \\
\text { Language Teacher }\end{array}$ & Mean & $\begin{array}{l}\text { Std. } \\
\text { Dev. }\end{array}$ \\
\hline \multirow{10}{*}{ 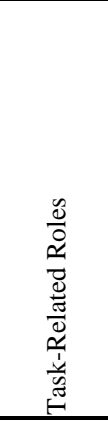 } & 1 & 1 & Communicator: He transmits information, content, thoughts to the pupils & 3.547 & 0.58 \\
\hline & 2 & 15 & Pupil guide: He directs pupils in the conduct and way of life & 3.322 & 0.69 \\
\hline & 3 & 22 & $\begin{array}{l}\text { Taskmaster: He assigns tasks, listens to recitations, asks questions, corrects answers and } \\
\text { assigns marks }\end{array}$ & 3.302 & 0.72 \\
\hline & 4 & 4 & Consultant: He enjoys the confidence of pupils and advises them & 3.282 & 0.73 \\
\hline & 5 & 12 & Monitor: He monitors the course of true education in every aspect & 3.265 & 0.74 \\
\hline & 6 & 21 & Demonstrator: He shows and explains to his students what he is doing & 3.257 & 0.75 \\
\hline & 7 & 16 & Professionalist: He keeps himself awake for his professional growth & 3.233 & 0.73 \\
\hline & 8 & 26 & $\begin{array}{l}\text { Midwife: He guides the pupil's thought processes by asking him the questions that will lead } \\
\text { him eventually to come to wise conclusions }\end{array}$ & 3.224 & 0.71 \\
\hline & 9 & 19 & Supporter: He supports students by providing material and physical facilities to help & 3.171 & 0.80 \\
\hline & 10 & 2 & $\begin{array}{l}\text { Counselor: He understands his pupils' personal and academic problems and acquaints them } \\
\text { with post-educational choices }\end{array}$ & 3.127 & 0.68 \\
\hline \multirow{7}{*}{ 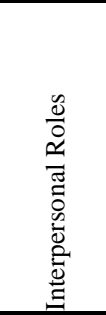 } & 1 & 3 & Collaborator: He joins hands in performing his task with his colleagues & 3.376 & 0.67 \\
\hline & 2 & 28 & Persuader: He is able to persuade his pupils to accept his views & 3.331 & 0.70 \\
\hline & 3 & 6 & Evaluator of pupils' learning in terms of their achievements, abilities and lapses & 3.322 & 0.71 \\
\hline & 4 & 24 & $\begin{array}{l}\text { Surrogate parent: He feels responsible for the learner as a whole: his health, social adjustment, } \\
\text { recreation, emotional health, character development, intellectual development... and so on }\end{array}$ & 3.180 & 0.78 \\
\hline & 5 & 29 & Propagandist: He sometimes wants his pupils to accept a pre-established point of view & 3.094 & 0.79 \\
\hline & 6 & 18 & $\begin{array}{l}\text { Agent of social change: He changes in social environment and perspective to realize the } \\
\text { objectives of a progressive society }\end{array}$ & 3.065 & 0.73 \\
\hline & 7 & 5 & Cultural Agent: He seeks to preserve and transmit the cultural heritage to posterity & 3.020 & 0.82 \\
\hline \multirow{9}{*}{ 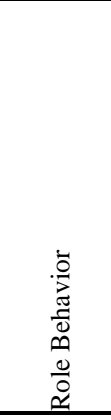 } & 1 & 23 & Disciplinarian: He maintains order in the classroom so as to control it & 3.392 & 0.68 \\
\hline & 2 & 27 & $\begin{array}{l}\text { Evangelist: He asks his pupils to live virtuous lives and lead them to the way of goodness } \mathrm{He} \\
\text { asks the pupils not to lie, steal, attack their classmates or cheat on examinations }\end{array}$ & 3.380 & 0.74 \\
\hline & 3 & 11 & Model: He commands perfection as a teacher and serves as a source of inspiration & 3.282 & 0.75 \\
\hline & 4 & 8 & Instructor: He imparts instructions by way of direction and order & 3.196 & 0.76 \\
\hline & 5 & 9 & Leader: He acts as a leader in the matter of educational reconstruction & 3.171 & 0.73 \\
\hline & 6 & 7 & Innovator: He innovates, performs, and improves the techniques, content, activities... etc. & 3.094 & 0.76 \\
\hline & 7 & 25 & $\begin{array}{l}\text { Therapist: He takes responsibility for the psychological problems and mental health of his } \\
\text { pupils }\end{array}$ & 3.053 & 0.87 \\
\hline & 8 & 14 & $\begin{array}{l}\text { Organizer of pupils' activities and supervises approved program of activities in and outside the } \\
\text { school }\end{array}$ & 3.004 & 0.79 \\
\hline & 9 & 10 & Manager: He organizes, supervises, and manages institutional affairs and problems & 2.984 & 0.78 \\
\hline \multirow{5}{*}{$\begin{array}{l}\frac{\tilde{U}}{0} \\
\mathcal{\alpha} \\
\frac{\pi}{0} \\
\frac{\tilde{U}}{2} \\
\tilde{2}\end{array}$} & 1 & 13 & Motivator: He stimulates and sustains active interest through various techniques & 3.514 & 0.62 \\
\hline & 2 & 20 & $\begin{array}{l}\text { Moral Booster: He not only believes righteously but also encourages uprightness among his } \\
\text { pupils }\end{array}$ & 3.404 & 0.68 \\
\hline & 3 & 17 & Promoter: He contributes to the growth and welfare of his students & 3.249 & 0.76 \\
\hline & 4 & 30 & $\begin{array}{l}\text { Human being: He has his own needs, interests, weaknesses, strengths He can play many roles } \\
\text { effectively }\end{array}$ & 3.184 & 0.70 \\
\hline & 5 & 31 & $\begin{array}{l}\text { Researcher: He can carry out classroom research and solve the problems of his classrooms } \\
\text { especially through so-called action research }\end{array}$ & 3.139 & 0.78 \\
\hline
\end{tabular}


APPENDIX D APPLICABILITY CORRELATION COEFFICIENTS BETWEEN THE ITEMS WITH THE DOMAINS AND THE WHOLE SCALE

\begin{tabular}{|c|c|c|c|c|}
\hline \multirow[t]{2}{*}{ Domain } & \multirow{2}{*}{$\begin{array}{l}\text { Item } \\
\text { ID }\end{array}$} & \multirow{2}{*}{$\begin{array}{l}\text { Level of Applicability } \\
\text { on Language Teacher }\end{array}$} & \multicolumn{2}{|c|}{$\begin{array}{l}\text { Correlation } \\
\text { With: }\end{array}$} \\
\hline & & & Domain & Scale \\
\hline \multirow{10}{*}{ 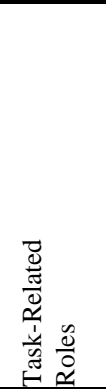 } & 1 & Communicator: He transmits information, content, thoughts to the pupils & 0.46 & 0.43 \\
\hline & 2 & $\begin{array}{l}\text { Counselor: He understands his pupils' personal and academic problems and acquaints them with post- } \\
\text { educational choices }\end{array}$ & 0.45 & 0.38 \\
\hline & 4 & Consultant: He enjoys the confidence of pupils and advises them & 0.58 & 0.51 \\
\hline & 12 & Monitor: He monitors the course of true education in every aspect & 0.55 & 0.51 \\
\hline & 15 & Pupil guide: He directs pupils in the conduct and way of life & 0.59 & 0.55 \\
\hline & 16 & Professionalist: He keeps himself awake for his professional growth & 0.54 & 0.51 \\
\hline & 19 & Supporter: He supports students by providing material and physical facilities to help & 0.59 & 0.55 \\
\hline & 21 & Demonstrator: He shows and explains to his students what he is doing & 0.62 & 0.58 \\
\hline & 22 & Taskmaster: He assigns tasks, listens to recitations, asks questions, corrects answers and assigns marks & 0.60 & 0.58 \\
\hline & 26 & $\begin{array}{l}\text { Midwife: He guides the pupil's thought processes by asking him the questions that will lead him eventually } \\
\text { to come to wise conclusions }\end{array}$ & 0.60 & 0.58 \\
\hline \multirow{7}{*}{ 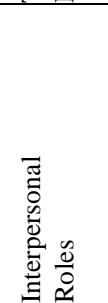 } & 3 & Collaborator: He joins hands in performing his task with his colleagues & 0.49 & 0.43 \\
\hline & 5 & Cultural Agent: He seeks to preserve and transmit the cultural heritage to posterity & 0.58 & 0.47 \\
\hline & 6 & Evaluator of pupils' learning in terms of their achievements, abilities and lapses & 0.59 & 0.44 \\
\hline & 18 & $\begin{array}{l}\text { Agent of social change: He changes in social environment and perspective to realize the objectives of a } \\
\text { progressive society }\end{array}$ & 0.64 & 0.63 \\
\hline & 24 & $\begin{array}{l}\text { Surrogate parent: He feels responsible for the learner as a whole: his health, social adjustment, recreation, } \\
\text { emotional health, character development, intellectual development... and so on }\end{array}$ & 0.56 & 0.49 \\
\hline & 28 & Persuader: He is able to persuade his pupils to accept his views & 0.58 & 0.56 \\
\hline & 29 & Propagandist: He sometimes wants his pupils to accept a pre-established point of view & 0.58 & $\mathbf{0 . 5 5}$ \\
\hline \multirow{9}{*}{ 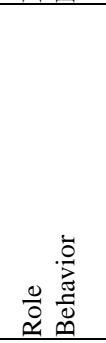 } & 7 & Innovator: He innovates, performs, and improves the techniques, content, activities... etc. & 0.54 & 0.51 \\
\hline & 8 & Instructor: He imparts instructions by way of direction and order & 0.48 & 0.34 \\
\hline & 9 & Leader: $\mathrm{He}$ acts as a leader in the matter of educational reconstruction & 0.53 & 0.49 \\
\hline & 10 & Manager: He organizes, supervises, and manages institutional affairs and problems & 0.57 & 0.48 \\
\hline & 11 & Model: He commands perfection as a teacher and serves as a source of inspiration & 0.60 & 0.49 \\
\hline & 14 & Organizer of pupils' activities and supervises approved program of activities in and outside the school & 0.50 & 0.43 \\
\hline & 23 & Disciplinarian: He maintains order in the classroom so as to control it & 0.49 & 0.45 \\
\hline & 25 & Therapist: He takes responsibility for the psychological problems and mental health of his pupils & 0.65 & 0.60 \\
\hline & 27 & $\begin{array}{l}\text { Evangelist: He asks his pupils to live virtuous lives and lead them to the way of goodness He asks the } \\
\text { pupils not to lie, steal, attack their classmates or cheat on examinations }\end{array}$ & 0.54 & 0.49 \\
\hline \multirow{5}{*}{ 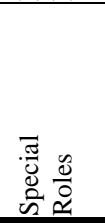 } & 13 & Motivator: He stimulates and sustains active interest through various techniques & 0.52 & 0.44 \\
\hline & 17 & Promoter: He contributes to the growth and welfare of his students & 0.66 & 0.63 \\
\hline & 20 & Moral Booster: He not only believes righteously but also encourages uprightness among his pupils & 0.64 & 0.51 \\
\hline & 30 & Human being: He has his own needs, interests, weaknesses, strengths He can play many roles effectively & 0.68 & 0.50 \\
\hline & 31 & $\begin{array}{l}\text { Researcher: He can carry out classroom research and solve the problems of his classrooms especially } \\
\text { through so-called action research }\end{array}$ & 0.68 & 0.56 \\
\hline
\end{tabular}


Appendix E: Table 3 Practice Correlation Coefficients Between the Items with the Domains and the WHOLE SCALE

\begin{tabular}{|c|c|c|c|c|}
\hline \multirow[t]{2}{*}{ Domain } & \multirow{2}{*}{$\begin{array}{l}\text { Item } \\
\text { ID }\end{array}$} & \multirow{2}{*}{$\begin{array}{l}\text { Level of Practice by } \\
\text { Language Teacher }\end{array}$} & \multicolumn{2}{|c|}{$\begin{array}{l}\text { Correlation } \\
\text { With: }\end{array}$} \\
\hline & & & Domain & Scale \\
\hline \multirow{10}{*}{ 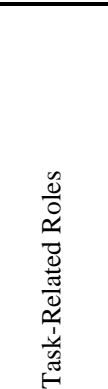 } & 1 & Communicator: He transmits information, content, thoughts to the pupils & 0.53 & $\mathbf{0 . 5 0}$ \\
\hline & 2 & $\begin{array}{l}\text { Counselor: He understands his pupils' personal and academic problems and acquaints them with post- } \\
\text { educational choices }\end{array}$ & 0.51 & 0.44 \\
\hline & 4 & Consultant: He enjoys the confidence of pupils and advises them & 0.42 & 0.34 \\
\hline & 12 & Monitor: He monitors the course of true education in every aspect & 0.63 & 0.60 \\
\hline & 15 & Pupil guide: He directs pupils in the conduct and way of life & 0.50 & 0.43 \\
\hline & 16 & Professionalist: He keeps himself awake for his professional growth & 0.61 & 0.56 \\
\hline & 19 & Supporter: He supports students by providing material and physical facilities to help & 0.56 & 0.52 \\
\hline & 21 & Demonstrator: He shows and explains to his students what he is doing & 0.65 & 0.63 \\
\hline & 22 & Taskmaster: He assigns tasks, listens to recitations, asks questions, corrects answers and assigns marks & 0.59 & 0.59 \\
\hline & 26 & $\begin{array}{l}\text { Midwife: He guides the pupil's thought processes by asking him the questions that will lead him } \\
\text { eventually to come to wise conclusions }\end{array}$ & 0.59 & 0.59 \\
\hline \multirow{7}{*}{ 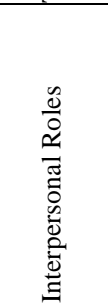 } & 3 & Collaborator: He joins hands in performing his task with his colleagues & 0.54 & 0.44 \\
\hline & 5 & Cultural Agent: He seeks to preserve and transmit the cultural heritage to posterity & 0.60 & 0.49 \\
\hline & 6 & Evaluator of pupils' learning in terms of their achievements, abilities and lapses & 0.63 & 0.53 \\
\hline & 18 & $\begin{array}{l}\text { Agent of social change: He changes in social environment and perspective to realize the objectives of a } \\
\text { progressive society }\end{array}$ & 0.67 & 0.60 \\
\hline & 24 & $\begin{array}{l}\text { Surrogate parent: He feels responsible for the learner as a whole: his health, social adjustment, recreation, } \\
\text { emotional health, character development, intellectual development... and so on }\end{array}$ & 0.52 & 0.51 \\
\hline & 28 & Persuader: He is able to persuade his pupils to accept his views & 0.57 & 0.56 \\
\hline & 29 & Propagandist: He sometimes wants his pupils to accept a pre-established point of view & 0.59 & $\mathbf{0 . 5 3}$ \\
\hline \multirow{9}{*}{ 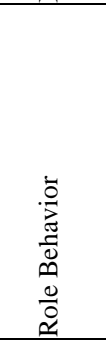 } & 7 & Innovator: He innovates, performs, and improves the techniques, content, activities... etc. & 0.57 & 0.48 \\
\hline & 8 & Instructor: He imparts instructions by way of direction and order & 0.42 & 0.26 \\
\hline & 9 & Leader: $\mathrm{He}$ acts as a leader in the matter of educational reconstruction & 0.58 & 0.47 \\
\hline & 10 & Manager: He organizes, supervises, and manages institutional affairs and problems & 0.51 & 0.39 \\
\hline & 11 & Model: He commands perfection as a teacher and serves as a source of inspiration & 0.64 & 0.52 \\
\hline & 14 & Organizer of pupils' activities and supervises approved program of activities in and outside the school & 0.44 & 0.36 \\
\hline & 23 & Disciplinarian: He maintains order in the classroom so as to control it & 0.54 & 0.46 \\
\hline & 25 & Therapist: He takes responsibility for the psychological problems and mental health of his pupils & 0.54 & 0.54 \\
\hline & 27 & $\begin{array}{l}\text { Evangelist: He asks his pupils to live virtuous lives and lead them to the way of goodness He asks the } \\
\text { pupils not to lie, steal, attack their classmates or cheat on examinations }\end{array}$ & 0.45 & $\mathbf{0 . 4 3}$ \\
\hline \multirow{5}{*}{ 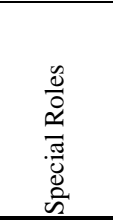 } & 13 & Motivator: He stimulates and sustains active interest through various techniques & 0.61 & 0.56 \\
\hline & 17 & Promoter: He contributes to the growth and welfare of his students & 0.72 & 0.61 \\
\hline & 20 & Moral Booster: He not only believes righteously but also encourages uprightness among his pupils & 0.63 & 0.52 \\
\hline & 30 & Human being: He has his own needs, interests, weaknesses, strengths He can play many roles effectively & 0.65 & 0.47 \\
\hline & 31 & $\begin{array}{l}\text { Researcher: He can carry out classroom research and solve the problems of his classrooms especially } \\
\text { through so-called action research }\end{array}$ & 0.59 & 0.47 \\
\hline
\end{tabular}

\section{REFERENCES}

[1] Arafat, S. (2005). The roles of English Language teachers as perceived by learners of English as a foreign language at AnNajah National University. An-Najah Univ. J. Res. (H. Sc.), 19, 2, 679-722.

[2] Banten, Michael. (1965). An introduction to the study of social relations. London: Tavistock Publications.

[3] Breen, M., and C. N. Candlin. (1980). The essentials of communicative curriculum in language teaching. Applied Linguistics 1, 2, 89-112.

[4] Brinton D. M., M. A. Snow, \& Wesche, M. B. (1989). Content-Based Second Language Instruction. New York: Newbury House.

[5] Brown, H. D. (2001). Teaching by Principles: An interactive approach to language pedagogy. White Plains, New York:Addison Wesley Longman, Inc.

[6] Byrne, D. (1976). Teaching Oral English. London: Longman.

[7] Choudhury, A. S. (2011). Classroom roles of English Language teachers: The traditional and the innovative. Contemporary Online Language Education Journal, 1, 33-40.

[8] Harden, R. M., and J. Crosby. (2000). The good teacher is more than a lecturer- the twelve roles of the teacher. AMEE Medical Education Guide, 20.

[9] Harmer, J. (2001). The practice of English Language teaching. London: Longman.

[10] Hinkle, Dennis, Weirsma, William \& Jurs, Stephen. (1988). Applied statistics for the behavioral sciences. Houghton Mifflin Company, Boston, (118): Rule of thumb for interpreting the size of a correlation coefficient.

[11] Jin, G. (2008). Application of communicative approach in college English teaching. Asian Social Science, 4, 4, 81-85.

[12] Huijie, Ding. (2012). Teacher's role in student-centered intensive reading class in China. Canadian Social Science, 8, 4, $62-66$. doi: 10.3968/j.css.1923669720120804.1157.

[13] Johnson, D., R. Johnson, \& Holubec, E. (1994). Cooperative learning in the classroom. Alexandria, Va.: Association for Supervision and Curriculum Development. 
[14] Keblowska, Magdalena. (2002). The role of the English language teacher in the classroom- The teachers' beliefs of the behavior versus the students' expectations. Studia Anglica Posnaniensia: International Review Of English Studies. Retrieved from http://www.thefreelibrary.com. August, 4, 2012, $12.40 \mathrm{pm}$.

[15] Lanier, Judith. (n.d.). Redefining the role of the teacher: It's a multifaceted profession. Retrieved from http://www.edutopia.org/redefining-role-teacher, August, 4, 2012, 10.31am.

[16] Littlewood, W. (1981). Communicative language teaching: An introduction. Cambridge: Cambridge University Press.

[17] Mohan, Chandrika. (2012). English Language teaching- updating the English classroom with techniques and communication skills. Language in India www.languageinindia.com, ISSN 1930-2940.

[18] Richards, J. C., and T. S. Rodgers. (2003). Approaches and methods in Language Teaching. Cambridge University Press.

[19] Simon, J. K. (2002). Perceptions of web-based instruction experts regarding the roles, outputs, and competencies needed in the field of web-based instruction needed in the field of web-based instruction: A model for training and development (Unpublished Ph. D. dissertation). Drake University, United States.

[20] Stevick, E. W. (1980). Teaching Languages: A way or ways. Rowley, Mass.: Newbury House.

[21] Shishavan, H. B. (2010). The relationship between Iranian English Language teachers and learners' gender and their perceptions of effective English Language teacher. English Language Teaching, 3, 3, 1-10.

[22] Veira, Ingrid. (2012). Roles of teachers in the $21^{\text {st }}$ century. Retrieved from http://www.pearsonclassroomlink.com, articles 10910/0910-0502.htm 10, 3.

[23] Willis, J. D. (1990). The Lexical Syllabus. London: Collins COBUILD.

[24] Yuveinco, J. C., \& Huang, S. (2005). Exploring ELT teacher's role within e-learning from student's perceptions. Journal of National Taipei Teachers College, 18, 1, 183-200.

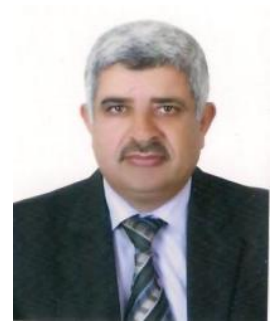

Mohammad Ahmed Al-Jabali was born in Rehaba, Irbid, Jordan in 1962. He got all his degrees from Yarmouk University, Irbid-Jordan. He got his B.A. in English Linguistics \& Literature in (1984), M. Ed. (1996) in TEFL, and Ph. D. (2007) in English Language Curricula and Instruction.

He worked as a teacher at Jordanian and Qatari schools. In February, 2008, he was appointed as an assistant professor at Jadara University for Graduate Studies (Jordan). In October 2011, he joined the Translation Center at King Saud University, Saudi Arabia. He published many studies in peer-reviewed international journals. His research interests are in teacher education, language acquisition, pragmatics, and translation.

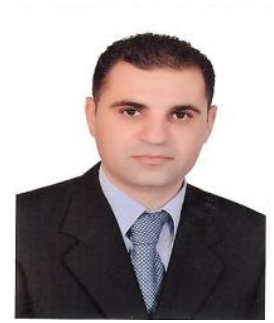

Mohammed Mahmoud Obeidat is an Assistant Professor of Translation at the Department of English Language and Translation, College of Languages and Translation- King Saud University. He completed his Ph. D. in Linguistics and Translation at the University of Salford/ a Greater Manchester University, UK in 2011.

He has been working for the College of Languages Translation of King Saud University, Saudi Arabia as Assistant Professor of translation since October 2011.

His area of specialization is teaching English >Arabic translation. He has taught translation in various academic institutions since 2007. His research revolves around translation studies, mostly contrastive analysis of Arabic and English originals and their translations into the other direction. He is also interested in the area of the translation of political discourse and ideology and translation. 